\title{
Workplace Competence Assessment and Development of Frontline Managers at Indian Power Companies
}

\author{
Ruchi Tyagi and Suresh Vishwakarma
}

\begin{abstract}
The paper identifies training needs for work place competence of front line managers at Indian power distribution companies (DISCOMs). DISCOMs' top managers were interviewed to develop questionnaire items. The findings include that frontline managers need training on few new technologies and commercial areas related to customer services.
\end{abstract}

Index Terms-Electricity customers, frontline managers, power distribution companies, training.

\section{INTRODUCTION}

The Indian power distribution sector has been witnessing a lot of activities like increased consumer demand, increased urbanization, rural electrification, and increased private sector participation in the recent years. The changing scenario is now anticipating strengthening of sales capabilities, total service capabilities, increased management efficiency and responsiveness, rationalizing and increasing the speed and efficiency of operations as well as strengthening internal auditing functions to reduce losses [1]. DISCOMs' manpower is not trained in the new technologies and practices resulting in performance deficiency and reduced customer satisfaction, demanding regular updating of employees' skills [2]. It is important to find which competences are resulting in performance deficiency and reduced customer satisfaction the present study focus on same. Most of the training programs, whether run in-house or conducted externally are attended only by those who can be spared to attend such training programs [3]. CEA [4] has stated that power sector reforms have led to change in the role of engineers from a purely government controlled technical management to business management in a corporatized framework. National Training Policy of India [5] states that training of staff at state electricity board was often neglected and ignored. DISCOMs' manpower is not trained in the new technologies and practices resulting in performance deficiency and reduced customer satisfaction, demanding regular updating of employees' skills [6]. World Bank's report [7] says that Restructured Accelerated Power Development and Reforms Programme (R-APDRP) initiatives can be successful only if the capacity of the utility staff is improved through appropriate skills and requisite training. Also, the distribution utilities need to focus on enhancing customer satisfaction by providing efficient and reliable service in India where $20 \%$ of customers account for

Manuscript received July 7, 2017; revised October 8, 2017.

Ruchi Tyagi is with the Department of Human Resources \& Organizational Behaviour, University of Petroleum and Energy Studies, Dehradun, India (e-mail: csractivist@yahoo.co.uk).
$80 \%$ of the revenue. Frontline managers heading DISCOMs' field offices are the key persons who practice most of the technologies and approaches to benefit customers of different categories. Thus we took following as the business problem to present research - the inadequate competency of frontline managers at Indian power distribution companies in new technologies and commercial practices are resulting in customers' dissatisfaction.

Research problem: The study would enquire the competency needs of DISCOMs' frontline managers on technical and commercial items for training need assessment.

\section{LITERATURE REVIEW}

Power Sector Reforms in India were identified as the key area to bring about the efficiency and improve financial health of the sector [8]. The Electricity Act of 2003 has paved the way for greater private sector participation into a hitherto public sector dominated space. The new areas of expertise emerged upon reforms and the consequent training requirements of the staff of power distribution companies especially at the frontline level has received some attention in few reports, journals, newspaper articles, training policies, and employees' unions during the past years. Customer satisfaction is increasingly important to retail electric utilities. Satisfying customers was important during the old days of utility regulation, when utility customers had little if any choice concerning their electricity supplier. It's even more important today, when customers can invest in equipment to bypass the grid in whole or in part, and it will inevitably be more pronounced in the future, when distributed generation options become more widespread and affordable [9]. Some of the thrust areas of the research conducted earlier to explore training needs assessment are illustrated briefly in Table I.

TABLE I: STUDIES UNDERTAKEN ON COMPETENCIES FOR CUSTOMER SERVICE IN INDIAN POWER DISTRIBUTION SECTOR

\begin{tabular}{|c|c|c|c|}
\hline $\begin{array}{l}\text { Sr. } \\
\text { No. }\end{array}$ & Author & Year & Dimensions \\
\hline 1 & $\begin{array}{l}\text { Kushwah and } \\
\text { Bhargav [10] }\end{array}$ & 2014 & $\begin{array}{l}\text { Understanding customers' needs } \\
\text { and expectations. }\end{array}$ \\
\hline 2 & $\begin{array}{l}\text { Ramachandra and } \\
\text { Bilolikar [11] }\end{array}$ & 2014 & $\begin{array}{l}\text { Customers' grievances and } \\
\text { redressal }\end{array}$ \\
\hline 3 & Masoud [12] & 2013 & DISCOM-customer relations \\
\hline 4 & Mishra [13] & 2008 & $\begin{array}{l}\text { Educating customers on the } \\
\text { installation- safety, efficient usage, } \\
\text { and beneficial schemes }\end{array}$ \\
\hline 5 & $\begin{array}{l}\text { Zeithaml et al. } \\
{[14]}\end{array}$ & 2006 & DISCOM-customer relationship \\
\hline 6 & $\begin{array}{l}\text { Smith and Woods } \\
{[15]}\end{array}$ & 2004 & $\begin{array}{l}\text { Educating customers on energy } \\
\text { efficiency }\end{array}$ \\
\hline 7 & Purcell et al. [16] & 2003 & Quality customer services by staff \\
\hline
\end{tabular}




\section{METHODOLOGY AND DATA ANALYSIS}

TABLE II: DEMOGRAPHIC PROFILE OF CUSTOMERS

\begin{tabular}{llcc}
\hline \hline Variable & Category & $N=500$ & Percent \\
\hline Category of consumption & Domestic & 332 & 66.4 \\
& Commercial & 98 & 19.6 \\
& Industrial & 25 & 5 \\
& Agriculture & 28 & 5.6 \\
& Others & 17 & 3.4 \\
Age of Respondent & $20-30$ & 106 & 21.2 \\
& $31-40$ & 149 & 29.8 \\
& $41-50$ & 130 & 26 \\
Gender of respondent & Above 51 & 115 & 23 \\
& Male & 459 & 91.8 \\
Educational qualification & Female & 41 & 8.2 \\
& Below Graduate & 57 & 11.4 \\
& Graduate & 272 & 54.4 \\
& Master and above & 171 & 34.2 \\
\hline \hline
\end{tabular}

Sampling: The population included electricity customers of different categories. Since the population of electricity customers was in millions, 500 customers were selected for the study. 500 is the suggested sample size when the population is infinite (published tables). The study focused on central India. Table II represents the demographic profile of customers under study.

Testing of hypothesis on customers' agreement about the frontline managers was initially undertaken assuming null and alternate hypothesis. An assumed mean value of 4 (Agree) was considered for the responses to test the null hypothesis using Two-Tail test.

$$
\begin{aligned}
& \mathrm{H}_{0}: \mu \geq 4 \\
& \mathrm{H}_{1}: \mu<4
\end{aligned}
$$

\section{UNITS}

The results in Table III were obtained on applying ' $t$ ' test using SPSS software to the responses collected from customers at $95 \%$ significance level.

\begin{tabular}{|c|c|c|c|c|c|}
\hline & Statement & Mean & $\mathrm{SD}$ & $t$ & Sig. 2-tailed \\
\hline $\mathrm{C} 1$ & Your monthly consumption changed in last years & 4.17 & 0.8 & 4.460 & 0.000 \\
\hline $\mathrm{C} 2$ & Your expectations for DISCOM services changed in last few years. & 3.93 & 0.9 & -1.59 & 0.112 \\
\hline $\mathrm{C} 3$ & FLMs at DISCOMs understand your needs and expectations. & 2.97 & 1.1 & -19.4 & .000 \\
\hline $\mathrm{C} 4$ & FLMs adequately advise on electrical installation and its shortcomings. & 2.65 & 1.2 & -24.4 & .000 \\
\hline $\mathrm{C} 5$ & FLMs adequately educate on the installation related safety issues & 2.68 & 1.2 & -23.6 & .000 \\
\hline C6 & FLMs adequately advise on installation - energy efficiency measures & 2.72 & 1.2 & -22.6 & .000 \\
\hline $\mathrm{C} 8$ & $\begin{array}{l}\text { FLMs adequately advise and educate you on the responsibilities of electricity } \\
\text { customers. }\end{array}$ & 2.72 & 1.3 & -21.7 & .000 \\
\hline C9 & $\begin{array}{l}\text { FLMs adequately advise and educate you on the penalties for indulging in electricity } \\
\text { theft. }\end{array}$ & 2.89 & 1.4 & -17.7 & .000 \\
\hline $\mathrm{C} 10$ & $\begin{array}{l}\text { FLMs adequately educate you on the disadvantages of having low power factor in your } \\
\text { installation }\end{array}$ & 2.69 & 1.3 & -22.0 & .000 \\
\hline $\mathrm{C} 11$ & $\begin{array}{l}\text { FLMs adequately educate you on the disadvantages of having unbalanced load in your } \\
\text { installation }\end{array}$ & 2.73 & 1.4 & -19.7 & .000 \\
\hline $\mathrm{C} 12$ & $\begin{array}{l}\text { FLMs adequately educate you on the benefits of using energy efficient appliances in } \\
\text { your installation. }\end{array}$ & 2.62 & 1.3 & -22.6 & .000 \\
\hline $\mathrm{C} 13$ & $\begin{array}{l}\text { FLMs educate you on Bureau of Energy Efficiency's role and other Government's } \\
\text { schemes to help customers. }\end{array}$ & 2.66 & 1.4 & -21.3 & .000 \\
\hline $\mathrm{C} 14$ & $\begin{array}{l}\text { FLMs reflect creativity in their work in understanding and resolving customers' } \\
\text { problems. }\end{array}$ & 2.99 & 1.2 & -18.5 & .000 \\
\hline $\mathrm{C} 15$ & FLMs are commercial in their approach as they are technical & 3.18 & 1.1 & -16.2 & .000 \\
\hline C16 & FLMs are capable of positively influencing you as DISCOM customer & 2.87 & 1.4 & -17.3 & .000 \\
\hline $\mathrm{C} 17$ & FLMs have unbiased approach towards you as DISCOM customer & 2.79 & 1.2 & -21.0 & .000 \\
\hline C18 & FLMs track your pending grievances and follow up enough to address. & 2.73 & 1.3 & -20.8 & .000 \\
\hline $\mathrm{C} 19$ & FLMs put effort to ensure their staff's quality services & 2.92 & .96 & -25.0 & .000 \\
\hline $\mathrm{C} 20$ & FLMs put enough efforts to reduce supply outage. & 3.23 & 1.0 & -16.0 & .000 \\
\hline $\mathrm{C} 21$ & FLMs put enough efforts to increase DISCOM's revenue. & 3.37 & .90 & -15.4 & .000 \\
\hline $\mathrm{C} 22$ & Good communication and public relations are mandatory for FLM. & 3.86 & 1.3 & -2.31 & .121 \\
\hline $\mathrm{C} 25$ & FLMs show trust and empathy in listening facts and realize feelings & 3.04 & 1.2 & -17.2 & .000 \\
\hline $\mathrm{C} 26$ & FLMs are motivated and professional & 3.19 & 1.0 & -17.6 & .000 \\
\hline $\mathrm{C} 27$ & $\begin{array}{l}\text { FLMs are capable enough to identify customers' issues and conclude as much as } \\
\text { possible from available info. }\end{array}$ & 3.08 & 1.3 & -15.5 & .000 \\
\hline $\mathrm{C} 28$ & FLMs are capable to develop collaborative relations between DISCOM and customers. & 3.10 & 1.0 & -19.2 & .000 \\
\hline $\mathrm{C} 29$ & FLMs are precise in approaching DISCOM's work \& personal activities & 3.14 & .98 & -19.4 & .000 \\
\hline C30 & FLMs build DISCOM image as customer friendly & 3.09 & 1.1 & -17.0 & .000 \\
\hline $\mathrm{C} 31$ & FLMs are sensitive in dealing and refrain from any unpleasing behavior & 2.78 & 1.3 & -20.8 & .000 \\
\hline $\mathrm{C} 32$ & FLMs at work demonstrate team spirit and fellowship & 3.18 & 1.0 & -16.6 & .000 \\
\hline
\end{tabular}

TABLE III: ONe SAMPle Statistics (Assumed Test VALue - 4)

A positive correlation confirms that the customers' expectations have also changed along with the change in their 
electricity consumption during the past years.

TABLE IV: CORRELATION BETWEEN CHANGE IN CONSUMPTION AND EXPECTATIONS

\begin{tabular}{lcc}
\hline \multicolumn{3}{c}{ EXPECTATIONS } \\
\hline \hline Channels & $\begin{array}{c}\text { Consumption } \\
\text { has changed }\end{array}$ & $\begin{array}{c}\text { Expectations have } \\
\text { changed }\end{array}$ \\
\hline Consumption change & & \\
Expectations have changed & $.552^{* *}$ & \\
Mean $(n=500)$ & 4.17 & 3.93 \\
$\mathrm{SD}$ & 0.852 & 0.983 \\
\hline \hline
\end{tabular}

Table III confirmed that the significant value for all 32 variables is less than 0.05 except for the variables -Expectations for services from the DISCOM have changed and Good communication and public relations skills are mandatory to perform FLMs' job at DISCOMs. The actual mean values are not equal to or greater than the assumed mean value of 4 except for increase in electricity consumption, which confirms that all the customers do not agree to the statements. Hence the null hypothesis is rejected and alternate hypothesis was accepted.

The mean values below 3 indicated that the customers do not agree to under-listed 18 skills. Frontline managers need to be trained adequately in these skills.

\begin{tabular}{cc} 
TABLE V: MEAN VALUES ON SKILLS \\
\hline \hline Sr. & Mean \\
\hline C3 & 2.97 \\
C4 & 2.65 \\
C5 & 2.68 \\
C6 & 2.72 \\
C7 & 2.92 \\
C8 & 2.72 \\
C9 & 2.89 \\
C10 & 2.69 \\
C11 & 2.73 \\
C12 & 2.62 \\
C13 & 2.66 \\
C14 & 2.99 \\
C16 & 2.87 \\
C17 & 2.79 \\
C18 & 2.73 \\
C19 & 2.92 \\
C23 & 2.97 \\
C31 & 2.78 \\
\hline \hline
\end{tabular}

Table III and IV suggest customer's do not believe that FLMs properly understand their needs as well as do not advise them adequately. They don't educate them either on energy efficiency, efficient installation, and safety related issues. Further, customers perceive mandatory good communication and public relations skills most important (mean value 3.86) to perform frontline managers' job at DISCOMs.

Customers have perceived the under-noted attributes with means (above 3 ) as crucial.

1) FLMs are equally commercial in their approach as they are technical at work.

2) FLMs are putting enough efforts to reduce supply outage in their area.

3) FLMs are putting enough efforts to increase DISCOM's revenue.

4) FLMs possess enough skills to promptly resolve your services and bills related grievances.

5) FLMs demonstrate trust and empathy in listening to your facts and understand feelings.

6) FLMs are adequately motivated and professional to make DISCOM progress and serve you better.

7) FLMs are capable enough to identify customers' issues \& conclude as much as possible from info available

8) FLMs are capable to develop collaborative relations between DISCOM \& customers for win-win situation.

9) FLMs are thorough and precise in approaching DISCOM's work and their personal activities.

10) FLMs try to build DISCOM a customer friendly company with good image in general public.

11) FLMs have team spirit and fellowship at their workplace to serve you better.

On the other hand, "FLMs adequately educate you on the benefits of using energy efficient appliances in your installation" is also an attribute FLMs must possess but as it has the lowest mean (2.62); it shows that customers do not perceive this attribute in DISCOMs' Frontline Managers as important.

Also the lowest SD 0.905 shows that customers are comprehensible on the issue- "If DISCOMs' frontline managers are putting enough efforts to increase DISCOM's revenue". High standard deviation (above 1.4) shows that customers are somewhat dubious on Frontline Managers' under-noted attributes

1) FLMs adequately advise and educate you on the penalties for indulging in theft of electricity.

2) FLMs adequately educate you on the disadvantages of having unbalanced load in your installation.

3) FLMs educate you on the role of Bureau of Energy Efficiency and other Government's initiatives.

4) FLMs are capable of positively influencing you to be a loyal and responsible customer of DISCOM.

Reliability and Validity of the instrument: Each item of the questionnaire was to be rated on five-point scale ranging on the continuum of Strongly Disagree to Strongly Agree. The reliability of the test ranged between 0.7 and 0.9 , and its construct validity (content and criterion) was established. Cronbach's Alpha value of 0.905 confirming internal consistency.

\section{CONCLUSION}

The study gives valuable information to DISCOMs' management as well as contributes to academics by giving supporting information on the impact of different variables to further the research on understanding what additional variables may also exist and how they can be remedied. DISCOMs' management may use these results to nurture and develop a suitable scenario in order to foster the performance of their frontline mangers. This study paves way to further this research in a larger geographical region to develop better understanding on the training needs of frontline managers in power distribution companies in all those developing countries where reforms have been lately introduced. The results may vary across social schemas and cultures. Future research should explore these issues. 


\section{REFERENCES}

[1] S. Sarkar, "Competency based training need assessment - approach in Indian companies," Organizacija, North America, vol. 46, Dec. 2013

[2] Ministry of Power, Document Quoted DISCOMs' Manpower Is not Trained in New Technologies \& Practices, 2012.

[3] PWC, "Changing rules of Indian power sector: Empowering the economy," Aug. 2015.

[4] CEA, "Training in electricity distribution sector in India," Information of Central Electricity Authority, 2012.

[5] Government of India, Ministry of Power, National Training Policy for the Power Sector, Article 1 and 5, June 2002.

[6] Ministry of Power, Document Quoted DISCOMs' Manpower Is not Trained in New Technologies \& Practices, 2012.

[7] More power to india: The challenge of distribution, World Bank's Report, p. 128, 2002.

[8] Ministry of Power, Govt. of India, Report of $10^{\text {th }}$ Five Year Plan, 2002.

[9] W. P. Zarakas, P. Q. Hansar, and K. Diep, "Rates reliability and region - customer satisfaction and electric utilities," Fortnightly, pp. 48-55, January 2013.

[10] V. Kushwah and A. Bhargav, "Service quality expectations and perceptions of telecom sector in India," International Journal of Advancements in Technology, vol. 5, no. 1, March 2014.

[11] U. Ramachandra and R. Bilolikar, "CRM practices in electricity distribution in India-supply side perspective: Improving service delivery for e-inclusion," LIRNEasia, Colombo, March, 2014

[12] E. Masoud, "The effect of perceived work environment on frontline employees' service recovery performance: The case of four and five star hotels in Jordan," European Scientific Journal, vol. 9, no. 11, April 2013 edition.

[13] S. Mishra. (2008). Power sector reforms in India: A critical appraisal of Orissa's reforms experience. [Online]. Available: www.scribd.com/doc/12915122/Power-Sector-Reforms-Orissa-Persp ective

[14] V. A. Zeithaml, M. J. Bitner, and D. D. Gremler, Services Marketing: Integrating Customer Focus across The Firm, 4th ed., New York: McGraw-Hill, 2006
[15] G. Smith and B. Wood, "Concept paper performance benchmarks for electricity distribution companies in South Asia," Nexant, pp. 3-11, Nov. 2004.

[16] J. Purcell, N. Kinnie, S. Hutchinson, B. Rayton, and J. Swart, Understanding the People and Performance Link: Unlocking the Black Box, London: Chartered Institute of Personnel and Development, 2003.

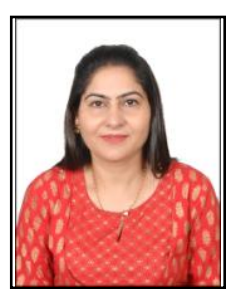

Ruchi Tyagi was born in India, Ruchi. She has got the $\mathrm{PhD}$ in management (CSR), MBA( HR ), diploma in labor laws and masters in journalism and mass communication. Her research interest are corporate social responsibility and sustainability; ICT in education.

She is presently an assistant professor at College of Management \& Economics Studies, University of Petroleum \& Energy Studies, Dehradun, India. She is a visiting faculty at few European Universities. She has more than 50 research papers publication to her credit Prof. Ruchi has coordinated several ICT programs in the past years.

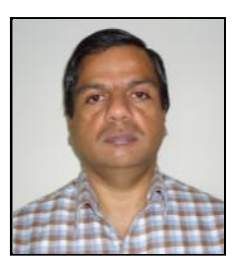

Suresh Vishwakarma was born in India, Suresh. He has got the degree in electrical engineering, MBA, and advanced certificate in power distribution management.

$\mathrm{He}$ is a registered professional engineer in Canada and Chartered Engineer in UK. He has worked at senior engineering positions with electric utility companies in India, Seychelles, and Canada since 1988. He has more than 25 paper and journal publications to his credit. Mr. Suresh is the IET (UK)'s Representative in Western Canada. 